\title{
Розробка автономних систем охолодження з урахуванням відновлювальних і непридатних джерел теплової енергії
}

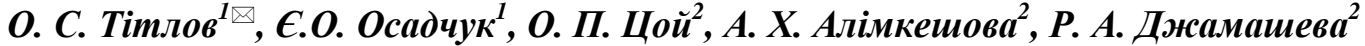 \\ ${ }^{1}$ Одеська національна академія харчових технологій, вул. Канатна, 112, Одеса, 65039, Україна \\ ${ }^{2}$ Алматинський технологічний університет, вул. Толе би, 100, м. Алмати, 050012, республіка Казахстан \\ $\triangle$ e-mail: titlov1959@gmail.comc
}

\begin{abstract}
Виконано аналіз можливостей використання нічного радіаційного випромінювання (НРВ) для додаткового відводу тепла від елементів системи рідинного охолодження. Показано енергетичні перспективи використання технологї НРВ для автономних первинних систем охолодження переважно в селянських господарствах, розташованих у віддалених місцевостях від джерел електричної енергії. Для підвищення енергетичної ефективності автономних систем охолодження запропоновано використовувати абсорбиійні водоаміачні холодильні машини (ABXM) і парокомпресійні холодильні машини (ПКХМ), які дозволять в світлий час доби створювати запаси холоду в системі холодоакумуляиіі. Для роботи АВХМ пропонується використовувати теплову енергію сонячного випромінювання. Розроблено алгоритм пошуку мінімальної температури гріючого джерела АВХМ в залежності від температур об'єкта охолодження і охолоджуючого середовища. Показано, щзо при реалізаиії традищійних ииклів АВХМ мають місие режими з максимальною енергетичною ефективністю, а для їх досягнення необхідна відповідна комбіначія складу робочого тіла (водоаміачного розчину) і температур гріючого джерела. Показано також, що при роботі від сонячних колекторів з водою в якості теплоносія, до складу схеми АВХМ необхідно включати бустер-компресор перед конденсатором аміаку. Виконано термодинамічний аналіз чиклів ПКХМ, що прачюють на дозволених в даний час робочих тілах. Відзначено високі енергетичні характеристики ПКХМ при роботі в умовах низьких температур атмосферного повітря. Так, при зниженні температури атмосферного повітря від $40{ }^{\circ} \mathrm{C}$ до $10^{\circ} \mathrm{C}$ в середньому має місие зростання холодильного коефіцієнта ичиклів ПКХМ в 4-6 разів, а для аміаку - в 17,3 рази. Розроблено оригінальні схеми систем первинного охолодження молока на базі ПКХМ і АВХМ з використанням технології НРО, що дозволяють працювати в автономному режимі з використанням мінімальної кількості електричної енергії.
\end{abstract}

Ключові слова: нічне радіаційне охолодження, сонячна абсорбиійна водоаміачна холодильна машина, охолодження молока

\section{doi: https://doi.org/10.15673/ret.v55i2.1357}

(C) The Author(s) 2019. This article is an open access publication

This work is licensed under the Creative Commons Attribution 4.0 International License (CC BY) http://creativecommons.org/licenses/by/4.0/

\section{1. Вступ}

Незважаючи на високі темпи індустріалізації і електрифікації в сучасному світі, в багатьох країнах $є$ значна кількість територій, де або відсутні джерела електропостачання, або їх якість незадовільна. Одним 3 таких прикладів $є$ фермерські та селянські господарства, які знаходяться в місцях заготівлі та первинної обробки продукції тваринного і рослинного походження.

Особливо гостро стоять проблеми якісного забезпечення первинної холодильної обробки м'ясних і молочних продуктів відповідно до технологічних вимог. Якщо в регіонах з холодним кліма- том можна ще використовувати відомі здавна технології застосування водного льоду [1], то в країнах 3 помірним i тропічним кліматом потрібно застосовувати тільки штучне охолодження.

3 усього спектра сучасного холодильного обладнання для вирішення задач автономного штучного охолодження найбільш ефективними, з енергетичної точки зору, по-перше, є парокомпресійні холодильні машини (ПКХМ), що працюють від дизель-генераторів або сонячних батарей [2].

По-друге - тепловикористовуючі абсорбціійних холодильні машини, джерелом теплової енергії для яких служать потоки нагрітих газів або рідин $[3,4]$. 
Як показав порівняльний аналіз, для умов роботи в автономному режимі можна використовувати тільки водоаміачні абсорбційні холодильні машини (АВХМ). На відміну від бромістолітіевих аналогів вони не вимагають обов'язкового рідинного охолодження теплороссіючих елементів (конденсатора, дефлегматора, абсорбера) і значно дешевше при виготовленні через доступність конструкційних матеріалів (вуглецевих сталей) [5]. При цьому якщо врахувати весь цикл виробництва електричної енергії на теплових станціях, то АВХМ за енергетичною ефективностю стають поряд з ПКХМ [6].

При розробці нової техніки необхідно пам'ятати про дефіцит і високу вартість органічних паливних ресурсів, особливо відчутні в даний час в світі.

Одночасно 3 цим посилюються і екологічні вимоги щодо зниження викидів парникових газів в атмосферу планети.

У зв'язку з цим актуальною стає завдання пошуку шляхів підвищення енергетичної ефективності автономних систем охолодження, як на базі ПКХМ, так і на базі АВХМ.

Найбільш раціональним буде комплексний підхід, коли розглядаються і зовнішній (особливості роботи в умовах, що змінюються протягом доби та пори року умовах тепловідведення в навколишнє середовище) і внутрішній фактор (вдосконалення термодинамічних циклів і схем).

\section{2. Аналіз літературних даних і постановка проблеми}

Останнім часом, у зв'язку з вимогою енергоефективності та скороченням часу використання синтетичних холодильних агентів (фреонів) холодильних систем, спостерігається стабільний інтерес до пасивних способів охолодження. Одним 3 таких способів $є$ охолодження за рахунок радіаційного випромінювання в космічний простір.

Будь-яка поверхня, звернена до нічного неба, при певних умовах може випромінювати більше теплової енергії, ніж отримувати назад від навколишнього середовища [7]. Даний ефект носить назву нічного радіаційного охолодження (НРО) i за рахунок нього можна підтримувати температуру теплоносія нижче температури навколишнього повітря.

Використання НРО в значній мірі визначається особливостями клімату того чи іншого регіону. $\mathrm{У}$ певних кліматичних умовах холодильні системи, що використовують радіаційне випромінювання будуть працювати більш ефективно, ніж в інших. Вплив клімату на роботу систем даного типу досліджувався в роботах [8-10].
Встановлено, що на можливість використання НРО впливають такі атмосферні параметри, як швидкістю вітру, вологість повітря, прозорість атмосфери для інфрачервоного випромінювання в діапазоні від 8 до 13 мікрометрів [10].

Дослідження роботи холодильних систем, що використовують НРО, проводилися в багатьох регіонах планети 3 різними кліматичними умовами. Це і північні райони Таїланду з вологим жарким кліматом [11] і Копенгаген, Мілан, Афіни [12]. Вивчалися режими охолодження офісних приміщень під час теплого періоду року (3 1травня по 30-вересня). Досліджено можливість охолодження матеріалу з фазовим переходом для акумулювання холоду, створюваного за допомогою НРО.

В Австралії [13] вартість системи охолодження намагалися знизити шляхом поєднання системи НРО 3 сонячними батареями (фото-вольтажнимі панелями). У всіх дослідженнях [11-13], в денний час охолодження радіатора (охолоджувального пристрою) нижче температури навколишнього середовища не досягалося, оскільки поглинена сонячна енергія перевищувала випромінюється теплове випромінювання.

Для підвищення інтенсивності радіаційного охолодження пропонуються матеріали з високою випромінювальною здатністю в інфрачервоній частині спектра [14]. Також для поліпшення результату, пропонується радіатор закрити поліетиленовою плівкою для зниження конвективного теплопритоку і пофарбувати його поверхню фарбою 3 високою випромінювальною здатністю [7], щоб він міг віддавати більшу кількість тепла за рахунок інфрачервоного випромінювання. Однак радіаційне охолодження в основному було здійсненно тільки в нічний час, оскільки відповідні матеріали з високою інфрачервоної випромінювальною здатністю не забезпечували охолодження в денний час $[15,16]$. Як барвник, зокрема, пропонується використовувати матеріал 3 великим вмістом з'єднання $\mathrm{TiO} 2$, що підвищує радіаційну здатність поверхні [17].

Дослідження щодо застосування радіаційне випромінювання для холодильних систем проводяться і для різко континентального клімату Казахстану $[8,14,18]$. Автори [18] показали, що в регіонах з різко-континентальним кліматом нічний радіаційне охолодження може бути використано для зниження температури рідини, що надходить періодично. Наприклад дана схема може використовуватися для первинного охолодження молока після його збору.

Теплорозсіючи елементи 3 площею поверхні, що випромінює, $4 \mathrm{~m}^{2}$, дозволяють забезпечувати протягом року холодопродуктивність установки 
від 140 Вт до 650 Вт, в залежності від погодних умов міста Усть-Каменогорськ.

Таким чином технологія НРО дозволяє продовжити період використання природного холоду протягом року і скоротити витрати електроенергії при роботі систем охолодження на базі ПКХМ.

Дослідження [19] показали, що при розробці і проектуванні систем охолодження на базі АВХМ необхідно підтримувати робочий діапазон температур в зоні генерації $120 \ldots 140{ }^{\circ} \mathrm{C}$ [19]. Так як основний парк сонячних колекторів становлять конструкції з водою в якості теплоносія [20], то цього недостатньо для повноцінної реалізації циклу АВХМ навіть в зоні помірного клімату [21].

Відомі технічні пропозиції щодо вирішення проблеми низьких температур в зоні генерації пари аміаку $[22,23]$, але автори не наводять жодних режимних характеристик для реалізації холодильного циклу.

Таким чином, на підставі вищеозначеного можна зробити висновок про перспективність використання технології НРО, як своєрідного альтернативного джерела холоду. Однак системи охолодження з НРО обмежені нічним часом доби і це звужує сферу їх застосування.

Для цілодобової роботи в усі періоди року необхідно знайти прийнятні технічні рішення, зокрема, з використанням штучного холоду. Для цього можна розглянути і тепловикористовуючі холодильні машини, що працюють на поновлюваних джерелах теплової енергії і парокомпресійні зі зниженим енергоспоживанням.

У зв'язку з цим слід провести методичні розробки та аналіз знайдених рішень.

\section{3. Мета і завдання дослідження}

Мета дослідження - розробити схеми і конструкції автономних систем охолодження на базі ПКХМ і АВХМ з використанням альтернативних поновлюваних і непридатних джерел енергії, в тому числі і з використанням технології НРО.

Для досягнення поставленої мети необхідно виконати такі завдання:

1. Провести аналітичні дослідження і аналіз циклів АВХМ в широкому діапазоні робочих термодинамічних параметрів (температур). Визначити енергетично ефективні режими роботи АВХМ і відповідні їм термодинамічні параметри, в першу чергу рівні температур гріючої і навколишнього середовища, об'єкта охолодження.

2. Провести аналіз циклів ПКХМ в широкому діапазоні робочих термодинамічних параметрів (температур) 3 використанням широко застосовуються в даний час в холодильній техніці робочих тілах: R134a; R717 (аміак); R22; R600 (ізобутан); R744 (вуглекислота). Вибрати робочі тіла, які за- безпечують максимальну енергетичну ефективність в широкому діапазоні температур навколишнього середовища.

3. Розробити перспективні схеми автономних систем охолодження на базі ПКХМ і АВХМ з використанням альтернативних поновлюваних джерел енергії, в тому числі і з використанням технології НРО.

\section{4. Моделювання циклів абсорбційних во- доаміачних холодильних машин}

Цикли АВХМ реалізуються в насосної і безнасосной схемою [19]. Робоче тіло насосних АВХМ - водоаміачних розчин (ВАР), безнасосной - ВАР з добавкою інертного газу (водню). Насосні схеми мають більш високу енегретіческую ефективність, але мають в своєму складі циркуляційний насос і не автономні. Безнасосні схеми автономні, але, в порівнянні 3 насосними схемами, менш енергетично ефективні і вимагають температуру гріючого джерела на рівні $160 \ldots 170{ }^{\circ} \mathrm{C}$ [24].

Однією з особливостей АВХМ є взаємозалежність температур в характерних процесах циклу температури гріючого середовища $t_{h}$, температури охолоджуючої середовища $t_{w}$, температури об'єкта охолодження $t_{o b}$. 3 трьох температур довільно можуть бути задані тільки дві [24].

Будь-яка холодильна установки повинна забезпечувати заданий рівень охолодження $\left(t_{o b}\right)$, а сама установка працювати у відповідних кліматичних умовах, тобто при заданій температурі охолоджуючої середовища $t_{w}$. Тому, реальним праметром, який може змінюватися $є$ тільки температура гріючого джерела $t_{h}$.

При проведенні розрахунків циклів АВХМ була розроблена підсистема бібліотечних функцій термодинамічних i теплофізичних властивостей чистого аміаку і ВАР, заснована на використанні стандартних функцій апроксимації (лінійної або сплайновой) системи МathCAD [25].

Для аналізу було обрано найбільш проста схема насосної АBХМ з двома регенеративними теплообмінниками - розчинів (РТР) і аміаку (РТА) [26].

Вихідними даними для розрахунку є: а) температура охолоджуючого середовища $t_{w}$;

б) температура об'єкта охолодження $t_{o b}$; в) перепади температур на елементах, які не відкрито враховують умови теплообміну і недорекуперацію тепла: $\Delta t_{o}$ - перепад температур між об'єктом охолодження і температурою кипіння аміаку в випарнику; $\Delta t_{h},-$ перепад температур між слабким ВАР і гріє джерелом тепла генератора; $\Delta t_{W K}, \Delta t_{W A}, \Delta t_{W D}$ -- температурний напір в конденсаторі, абсорбере, дефлегматорі з охолоджуючим середовищем; $\Delta t_{T O}$ - температурний напір між потоками слабкого i 
міцного ВАР на холодному кінці РТР; $\Delta t_{H}-$ перегрів пари аміаку в РТО.

Варійованим параметром є температура гріючого джерела тепла $t_{h}$.

На першому етапі досліджень за наведеним вище алгоритмом був виконаний пошук діапазонів температур гріє джерела $\left(t_{h}\right)$, який би задовольняв умовам роботи АВХМ $\left(t_{w}\right)$ і вимоги до об'єкта охолодження $\left(t_{o b}\right)$.

Актуальність дослідження пов'язана 3 тим, що не всі режими роботи АВХМ можуть бути організовані при недостатньо високій температурі що гріє джерела. Так, наприклад, рівень температур охолодження в випарнику вимагає відповідного рівня тиску Ро і в випарнику, і в абсорбере. Рівноважна температура міцного ВАР в абсорбере $t^{\prime \prime}{ }_{w . A}$ повинна бути вище температури охолоджуючої середовища, щоб забезпечити відведення теплоти абсорбції. Масова частка аміаку в міцному ВАР визначається значеннями тиску Ро і температури $t^{\prime \prime}{ }_{w . A}$, а для організації процесу абсорбції необхідна деяка зона дегазації - різниця масових часток аміаку в міцному і слабкому ВАР. У свою чергу масова частка аміаку в слабкому ВАР визначається значеннями тиску конденсації-генерації Ро і температурою гріючого джерела $t_{h}$.

Алгоритм пошуку робочих режимів АВХМ полягав у наступному. На першому етапі задавалися температури об'єкта охолодження мінус $30{ }^{\circ} \mathrm{C}$; мінус $15^{\circ} \mathrm{C}$; мінус $5{ }^{\circ} \mathrm{C}$.

Для кожного значення $t_{o b}$ проводився розрахунок 3 фіксованим значенням $t_{w} 3$ діапазоном $25 \ldots 43^{\circ} \mathrm{C}$ з кроком в $1{ }^{\circ} \mathrm{C}$. Для заданих значень $t_{o b}$ i $t_{w}$ проводився розрахунок кратності циркуляції за рівнянням (12) зі змінною $t_{h} 3$ кроком в $1{ }^{\circ} \mathrm{C}$. У разі, якщо чисельні значення кратності циркуляції ВАР позитивні, то робиться висновок, про те, що режим роботи $\mathrm{ABXM}$ може бути реалізований, а в іншому випадку - режим роботи не існує. Отримані залежності $\epsilon$ мінімально необхідні чисельні значення температур гріючого середовища для умов роботи реальних АВХМ.

Аналіз цих результатів показує, що АВХМ в системі з сонячним колектором на воді в якості теплоносія може знайти застосування тільки в системах кондиціонування повітря при температуpi охолоджуючої середовища не вище $36 . .37^{\circ} \mathrm{C}$. Для роботи в системах охолодження 3 температурами до мінус $30^{\circ} \mathrm{C}$ необхідна температура гріючої середовища $140 . .150^{\circ} \mathrm{C}$.

Як показав аналіз при низьких температурах охолоджуючої середовища і гріє джерела зона дегазації може мати негативні значення, тобто цикл АВХМ не може бути реалізований.

На другому етапі проведено аналіз циклів АВХМ і визначені їх енергетичні характеристики - коефіцієнт перетворення і робота циркуляційно- го насоса в залежності від температури що гріє джерела. Робота насоса визначалася з розрахунку холодильної потужності випарника, що дорівнює 1 кВт.

Температура об'єкта охолодження в розрахунках склала: мінус $5{ }^{\circ} \mathrm{C}$; мінус $15^{\circ} \mathrm{C}$; мінус $25^{\circ} \mathrm{C}$, температура охолоджуючої середовища: від $10^{\circ} \mathrm{C}$ до $32{ }^{\circ} \mathrm{C}$. Температурні напори $\Delta t_{W K}, \Delta t_{W A}, \Delta t_{W D}$, $\Delta t_{T O}, \Delta t_{H}$ були прийняті рівними $5^{\circ} \mathrm{C}$, а $\Delta t_{h}=10^{\circ} \mathrm{C}$. Мінімальна температура гріючої середовища при аналізі склала $90{ }^{\circ} \mathrm{C}$, максимальна $170{ }^{\circ} \mathrm{C}$. Значення мінімальної температури вибрано на кордоні реалізації циклів АВХМ, а максимальної - з урахуванням початку активної корозії конструкційний матеріал.

У зв'язку з тим, що на енергетичні характеристики АВХМ впливають всі три температурних рівня (гріючого середовища, об'єкта охолодження, охолоджуючої середовища), був виконаний аналітичний пошук енергозберігаючих режимів АВХМ.

Алгоритм пошуку наступний.

Фіксувалися температури об'єкта охолодження $t_{o b}$ (від мінус 30 до $15^{\circ} \mathrm{C}$ ) і охолоджуючої середовища $t_{w}$ (від 17 до $47^{\circ} \mathrm{C}$ ). Задавалися температури гріючого джерела $t_{h}$ в діапазоні температур від 45 до $150^{\circ} \mathrm{C}$.

В діапазоні робочих температур гріє джерела за наведеним вище алгоритмом визначався коефіцієнт перетворення циклу АВХМ. Фіксувалося максимальне значення коефіцієнта перетворення i відповідне значення температури що гріє джерела.

\section{5. Аналіз результатів моделювання робо- чих режимів ABXM}

Аналіз отриманих результатів розрахунку дозволяє зробити наступні висновки.

По-перше, в діапазоні розрахункових параметрів має місце максимум енергетичної ефективності АВХМ. Найбільш явно наявність максимуму для умов роботи при температурах охолоджуючої середовища $20-32{ }^{\circ} \mathrm{C}$ і низьких температурах об'єкта охолодження (мінус $25^{\circ} \mathrm{C}$ ).

При зниженні температур об'єкта охолодження максимум енергетичної ефективності зміщується в область високих температур гріючого середовища, а його чисельні значення зменшуються. Так, наприклад, при температурі охолоджуючої середовища $26^{\circ} \mathrm{C}$ і температурі об'єкта охолодження мінус $5{ }^{\circ} \mathrm{C}$ максимум коефіцієнта перетворення циклу АВХМ має місце при температурі об'єкта охолодження $110{ }^{\circ} \mathrm{C}$, при мінус $15^{\circ} \mathrm{C}$ - при $120^{\circ} \mathrm{C}$, при мінус $25^{\circ} \mathrm{C}$ - при $140{ }^{\circ} \mathrm{C}$, відповідно значення коефіцієнта перетворення складають: 0,$53 ; 0,44$; 0,34 .

Аналіз результатів розрахунку показав, що такий хід розрахункових залежностей пояснюєть- 
ся наступним. В області низьких температур гріючого середовища (до максимальних значень коефіцієнта перетворення) - високою кратністю циркуляції ВАР між генератором і абсорбером (від 6 до 112), яка обумовлена вузькою областю дегазації $(0,006 \ldots 0,033)$.

В області високих температур гріючого середовища (після максимальних значень коефіцієнта перетворення) - збільшенням частки води в паровому потоці водоаміачної суміші, що виходить 3 генератора. Так, наприклад, при температурі охолоджуючої середовища $26^{\circ} \mathrm{C}$ і температурі об'єкта охолодження мінус $5{ }^{\circ} \mathrm{C}$ зростання частки пара води в суміші становить від 0,036 до 0,408 , тобто більше, ніж в 10 разів.

У першому випадку мають місце додаткові теплопритоки в генератор з потоком міцного ВАР. У другому випадку, незважаючи на зниження кратності циркуляції ВАР, теплове навантаження в генераторі збільшується через додаткови енергетичні витрати на випарювання абсорбенту - води. Зростання теплового навантаження дефлегматора при цьому також збільшується більш, ніж в 10 разів (при температурі охолоджуючої середовища $26{ }^{\circ} \mathrm{C}$ i температурі об'єкта охолодження мінус $5{ }^{\circ} \mathrm{C}$ - від 0,024 кДж/кг до 2,200 кДж/кг).

Зменшення коефіцієнта перетворення циклу АВХМ при зниженні рівня температур об'єкта охолодження пояснюється тим, що для таких режимів потрібно ВАР з підвищеною часткою абсорбенту. Так, наприклад, при температурі охолоджуючої середовища $26{ }^{0} \mathrm{C}$ зниження температури об'єкта охолодження від мінус $5{ }^{\circ} \mathrm{C}$ до мінус $25^{0} \mathrm{C}$ вимагає зниження частки аміаку в слабкому ВАР від 0,439 до 0,129. При цьому, незважаючи на зниження теплового навантаження генератора через зменшення кратності циркуляції рідини, що випереджає несприятливий вплив на енергетичну ефективність циклу АВХМ надає процес додаткового випаровування пара води з ВАР.

У розрахунковому діапазоні у всіх випадках збільшення температури що гріє джерела призводить до різкого зменшення потужності циркуляційного насоса, що перекачує міцний розчин 3 абсорбера в генератор.

Як показали розрахунки, при температурах, що гріє джерела від $90{ }^{\circ} \mathrm{C}$ до $130{ }^{\circ} \mathrm{C}$ (в залежності від температури охолоджуючої середовища) потужність циркуляційного насоса має максимальне значення. Надалі із зростанням температури що гріє джерела спостерігається іiі асимптотичне зниження і повільне зменшення. Найбільші зміни при цьому відбувається при підвищених температурах охолоджуючого середовища $\left(32{ }^{\circ} \mathrm{C}\right)$. Отримані залежності для циркуляційного насоса збігаються 3 результатами досліджень інших авторів [3, 27]. Такий хід залежностей пояснюється збільшенням зони дегазації в абсорбері при зниженні масової частки аміаку в слабкому ВАР.

Таким чином, результати моделювання дозволяють визначити найбільш енергетично вигідні режими роботи АВXМ 3 різними джерелами теплової енергії (температури від 47 до $140{ }^{\circ} \mathrm{C}$ ) і проводити розробку систем охолодження для широкого діапазону температур охолодження (мінус $30 \ldots 15^{\circ} \mathrm{C}$ ).

\section{6. Розробка автономної системи охоло- дження 3 використанням ефекту нічного радіаційного охолодження}

\section{1. Система на базі ПКХМ}

Розглянемо для приклада, технологію НРО в системі охолодження молока на фермах (рис. 1, 2).

Пропонуються дві схеми 3 радіаційним охолодженням і резервної ПКХМ.

Схема 1 (рис. 1). У нічний час, коли відсутня сонячна радіація, рідкий хладоносій 43 низькою температурою замерзання подається за допомогою насоса 3 до теплорозсіючої панелі 9. Панель 9 встановлюється під відкритим небом і скидає тепло в космічний простір за рахунок радіаційного інфрачервоного випромінювання, а в атмосферне повітря за рахунок конвективного теплообміну. При відсутності теплового навантаження температура холодоносія і атмосферного повітря вирівнюється. При подальшій циркуляції спостерігається ефект НРО і хладоноситель охолоджується нижче температури атмосферного повітря до 5-10 $\mathrm{C}$ [28].

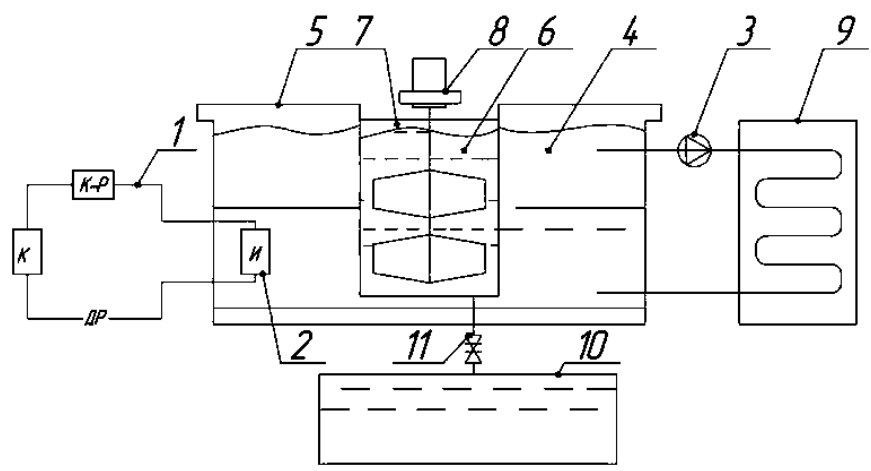

1 - ПКХМ, 2 - випарник ПКХМ, 3 - насос хладоносія, 4 - хладоносій, 5 - бак-акумулятор холоду, 6 - молоко, 7 - ємність для молока, 8 - мішалка, 9 - теплорозсіюча панель, 10 - бак для охолодженого молока, 11 - запорний вентиль

Рисунок 1 - Система охолодження молока з використанням НРО і ПКХМ

Хладоносій 4 далі надходить в бакакумулятор 5 і охолоджує бак 7 з молоком 6. Якщо хладоносій 4 не може охолодити молоко до необ- 
хідної температури, то підключають ПКХМ 1. Випарник 2 ПКХМ 1 охолоджує хладоносій 4 i молоко 6 до потрібної температури. Мішалка 8 інтенсифікує процес охолодження молока 6. Після охолодження молока 6 до необхідної температури, відкривається запірний вентиль 11 і проводиться злив продукту в бак 10.

Схема 2 (рис. 2). Випарник 10 ПКХМ 9 розташовується в нижній частині і всередині корпуса бака-охолоджувача 4. У верхній частині корпуса бака-охолоджувача 4 встановлюється зрошувач 53 отворами для рівномірної подачі насосом 6 холодної води з акумулятора холоду 2.

Теплорозсіюча панель 1 розташована під відкритим небом під кутом $10-30{ }^{\circ} \mathrm{C}$ в напрямку півночі. При НРО хладоносій в радіаторі 1 охолоджується нижче атмосферного повітря на $5-10{ }^{\circ} \mathrm{C}$ [28] і надходить в теплообмінник 7 , де охолоджує воду до потрібної температури.

Система охолодження працює ефективно в холодні сезони року і без ПКХМ, коли температура атмосферного повітря не перевищує $10-12{ }^{\circ} \mathrm{C}$, особливо в нічний час.

У теплу пору року система охолодження ефективна тільки вночі. Запас холоду за рахунок НРО забезпечує попереднє охолодження молока, а потім вже підключається ПКХМ. В цьому випадку відключають насос 6 і циркуляцію здійснюють насосом 13.

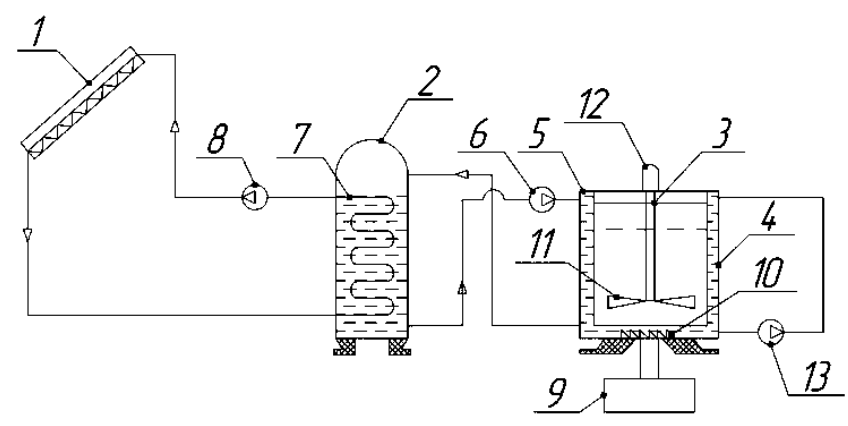

1 - теплорозсіюча панель, 2 - бак-акумулятор холоду, 3 - кришка бака-охолоджувача молока, 4 бак-охолоджувач молока, 5 - трубопровід з отворами, 6 і 13 - насос для води, 7 - теплообмінник, 8 насос для хладоносія, 9 - ПКХМ, 10 - випарник ПКХМ, 11 - мішалка, 12 - мотор-редуктор мішалки

\section{Рисунок 2 - Система охолодження молока з вико- ристанням НРО і ПКХМ}

При включенні в схеми систем охолодження ПКХМ необхідно оцінити їх енергетичну ефективність при роботі в широкому діапазоні температур атмосферного повітря. Слід оцінити можливість застосування дозволених в даний час холодильних агентів для умов роботи ПКХМ в складі систем охолодження молока з ефектом НРО.

Для проведення оцінки було проведено розрахунок термодинамічних параметрів циклу ПКХМ без регенеративного теплообмінника і переохладителя рідини перед дроселюванням. При розрахунку використані робочі тіла ПКХМ: R134a; R717 (аміак); R22; R600 (ізобутан); R744 ( $\left.\mathrm{CO}_{2}\right)$. Температура кипіння робочих тел ПКХМ приймалася рівною $t_{o}=0{ }^{\circ} \mathrm{C}$, а температура конденсації варіювалася в такий спосіб: $t_{k}=10 ; 20 ; 30 ; 40^{\circ} \mathrm{C}$.

При розрахунку використовувався класичний алгоритм [29] з визначенням в характерних точках циклу температур, тисків кипіння $\left(P_{\mathrm{o}}\right)$ і конденсації $\left(P_{\mathrm{k}}\right)$ і розрахунку питомої холодопродуктивності $\left(q_{\text {o }}\right)$, питомої роботи стиснення в компресорі $(l)$, коефіцієнта перетворення (СОР). Результати розрахунків наведені в таблиці 1 .

Таблиця 1 - Результати розрахунків термодинамічних параметрів і енергетичних характеристик циклів ПКХМ

\begin{tabular}{|c|c|c|c|c|c|c|}
\hline $\begin{array}{c}\text { Наймену- } \\
\text { вання робо- } \\
\text { чого тіла } \\
\text { ПКХМ }\end{array}$ & $\begin{array}{l}t_{k,} \\
{ }^{\circ} \mathrm{C}\end{array}$ & $\begin{array}{l}P_{\mathrm{o}}, \\
\text { бар }\end{array}$ & $\begin{array}{l}P_{\mathrm{k}}, \\
\text { бар }\end{array}$ & $\begin{array}{c}q_{\mathrm{o},} \\
\text { кДж/кг }\end{array}$ & $\begin{array}{c}l, \\
\text { кДж/кг }\end{array}$ & $C O P$ \\
\hline \multirow{4}{*}{ R134a } & 10 & 3,0 & 4 & 185 & 15 & 18,5 \\
\hline & 20 & 3,0 & 5,6 & 170 & 22 & 7,7 \\
\hline & 30 & 3,0 & 7,5 & 155 & 25 & 6,2 \\
\hline & 40 & 3,0 & 9,8 & 140 & 32 & 4,3 \\
\hline \multirow{4}{*}{ R717 } & 10 & 4,3 & 6 & 1260 & 10 & 127 \\
\hline & 20 & 4,3 & 8,5 & 1200 & 40 & 30 \\
\hline & 30 & 4,3 & 12,5 & 1160 & 100 & 11,6 \\
\hline & 40 & 4,3 & 16,5 & 1100 & 150 & 7,3 \\
\hline \multirow{4}{*}{ R22 } & 10 & 5,0 & 7 & 193 & 7 & 27,5 \\
\hline & 20 & 5,0 & 9 & 181 & 17 & 10,6 \\
\hline & 30 & 5,0 & 12 & 165 & 27 & 6,1 \\
\hline & 40 & 5,0 & 16 & 153 & 36 & 4,25 \\
\hline \multirow{4}{*}{ R600 } & 10 & 1,6 & 2,3 & 325 & 12 & 27 \\
\hline & 20 & 1,6 & 3 & 300 & 15 & 20 \\
\hline & 30 & 1,6 & 4 & 275 & 35 & 7,8 \\
\hline & 40 & 1,6 & 5,3 & 255 & 50 & 5,1 \\
\hline \multirow{3}{*}{ R744 } & 10 & 35,0 & 45 & 210 & 8 & 26,2 \\
\hline & 20 & 35,0 & 58 & 177 & 18 & 9,8 \\
\hline & 30 & 35,0 & 72 & 133 & 28 & 4,75 \\
\hline
\end{tabular}

Аналіз результатів розрахунку, наведених в таблиці 1 показує, що:

a) зниження рівня температур атмосферного повітря від $40{ }^{\circ} \mathrm{C}$ до $10{ }^{\circ} \mathrm{C}$ сприятливо позначається на енергетичній ефективності циклів ПКХМ, так, в середньому має місце зростання коефіцієнта перетворення в 4-6 разів, а для аміаку - в 17,3 рази;

б) максимальна енергетична ефективність циклу ПКХМ серед розглянутих робочих тіл відзначена у аміаку.

Проблеми, пов'язані 3 токсичним впливом аміаку на персонал, успішно вирішуються за рахунок зниження кількості заправки робочого тіла. 
Так, наприклад, в продукції фірми «Palm, KTH Sherpa project» на 9 кВт виробленого холоду припадає 99 грам аміаку [30].

\section{2. Система на базі АВXM}

Система охолодження (рис. 3-5) містить теплоізольованну ємність 13 кришкою 2. У нижній частині ємності 1 встановлено канал 3 запірним вентилем 3 для періодичного відведення охолодженого продукту. Збір і зберігання охолодженого молока здійснюється в ємності 4.

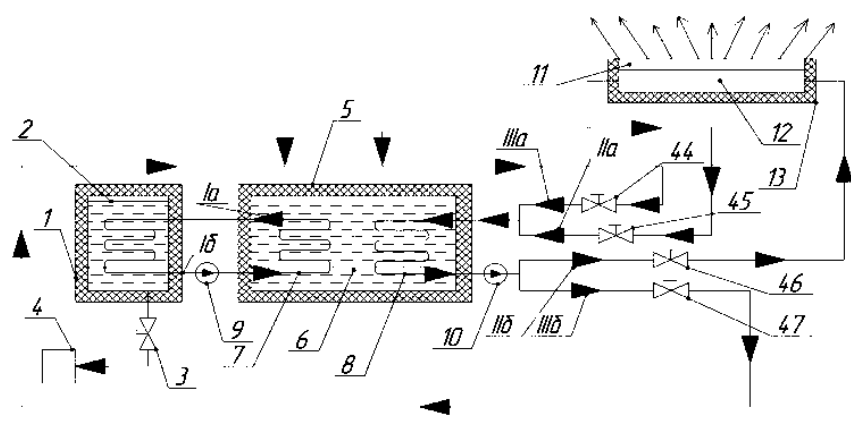

1 - ємність 3 молоком, 2 - кришка, 3 - запорний вентиль, 4 - ємність для молока, 5 - бак-акумулятор крижаної води, 6 - крижана вода, 7 м теплообмінник з водою, 8 - теплообмінник з розсолом, 9 - циркуляційний насос крижаної води, 10 - насос для розсолу, 11 м теплорассеівающіх панель, 12 - система каналів, 13 - теплоізоляційне покриття, 44, 45, 46 і 47 - вентилі

Рисунок 3 - Схема системи охолодження молока 3 теплоразсіючої панелю

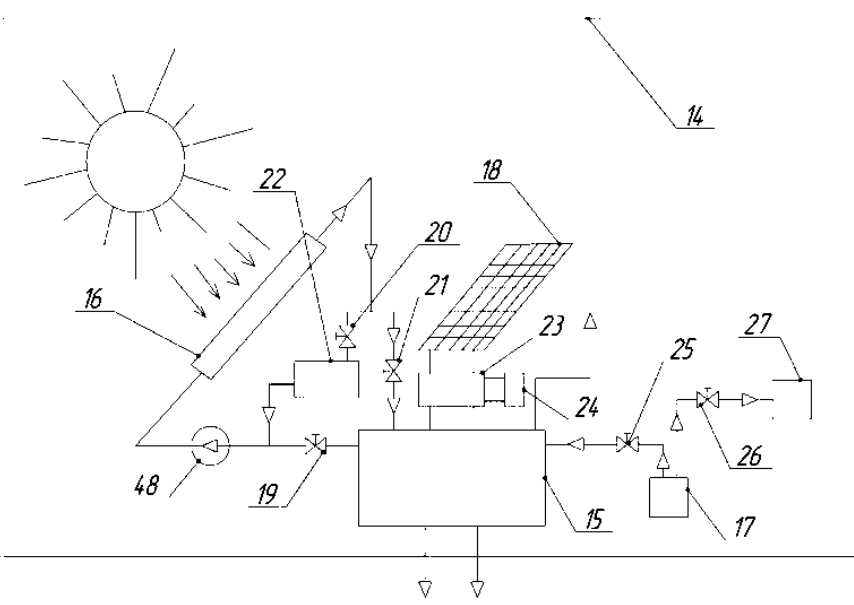

14 - холодильна система, 15 - АВХМ, 16 - сонячний колектор, 17 - генератор топкових газів, 18 сонячні батареї, 19, 20 і 21 - запірні вентилі, 22, 24 і 27 - споживачі тепла, 23 - система перетворення постійного струму, 25 і 26 - запірно-регулюючі вентилі, 48 - циркуляційний насос

Рисунок 4 - Система генерації штучного холоду

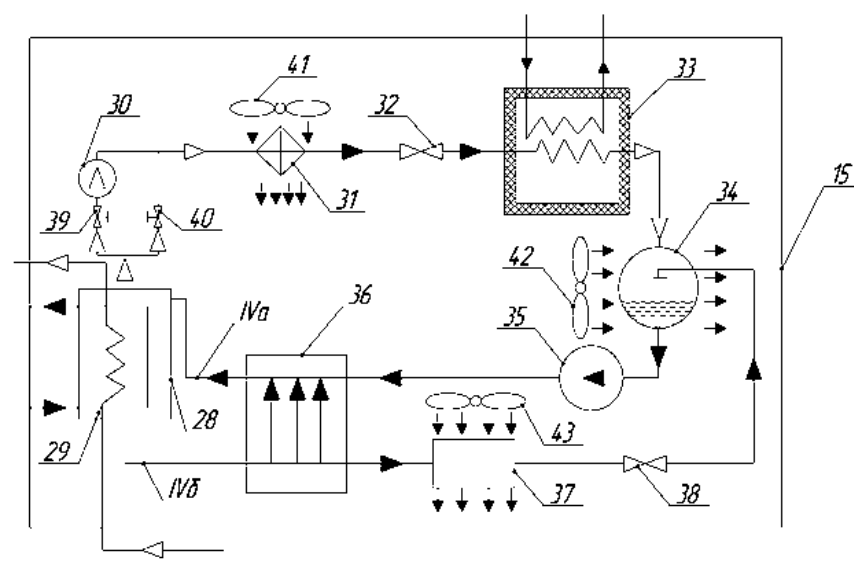

28 - генератор, 29 - ВАР, 30 - бустер-компресор, 31 - конденсатор 3 повітряним охолодженням, 32 - дросельний пристрій рідкого аміаку, 33 - випарник розсолу, 34 - абсорбер з повітряним охолодженням, 35 - циркуляційний насос міцного ВАР, 36 - регенеративний теплообмінник розчинів, 37 повітряний охолоджувач слабкого ВАР, 38 - дросельний пристрій слабкого ВАР, 39 і 40 - запірні вентилі, 41,42 і 43 - воздушні вентилятори теплоразсіючих елементів АВХМ

\section{Рисунок 5 - Схема АВХМ з бустер-компресором в} складі системи охолодження молока

Усередині ємності 1 по теплообміннику 7 циркулює крижана вода. Вхід холодного потоку розташований у верхній частині (Ia), а вихід - в нижній частині (Іб) ємності 1. Система охолодження містить також бак-акумулятор крижаної води 53 теплоізоляційним покриттям. Бак 5 заповнюється крижаною водою 6 з температурою, близькою до 0 - С. У внутрішньому обсязі бака-акумулятора 5 встановлені теплообмінники 7 і 8.

За теплообміннику 7 за допомогою насоса 9 циркулює крижана вода (потоки Іа і Іб), а по теплообміннику 8 за допомогою насоса 10 циркулює розсіл - незамерзаюча рідина, при температурі, близькій до $0^{\circ} \mathrm{C}$.

Вхід охолодженого потоку розсолу в бакакумулятор 5 (потоки ІІа і ІІІа) здійснюється у верхній частині, а вихід нагрітого потоку розсолу (потоки ІІб і ІІІб) з нижньої частини.

Система охолодження містить теплорассеівающіх металеву панель 11 . Панель 11 розташована або горизонтально, або з деяким кутом до горизонта. Верхня частина панелі покриті фарбою світлих кольорів. Панель 11 пов'язана в тепловому відношенні з системою каналів 12, по яких циркулює потоки розсолу Іа і ІІб. Система каналів 12 i нижня частина панелі 11 закривається теплоізоляційним покриттям 13.

До склада системи входить холодильна система на базі АВХМ 14 (рис. 4), призначена для 
охолодження потоків розсолу IIIa i IIIb. Управління потоками розсолу IІа, ІІб, ІІІа і ІІІб здійснюється за допомогою запірних вентилів, відповідно, 44, 45, 46 і 47. Холодильна система 14 містить АВХМ 15 системою підведення тепла від сонячного колектора 16 і генератора топкових газів 17, а також систему автономного електрозабезпечення на базі сонячних батарей 18 (рис. 5). Система сонячного колектора 16 містить циркуляційний насос 48 і систему запірних вентилів 19, 20, 21 забезпечують подачу гарячого теплоносія як на АВXМ 15, так і на інших споживачів тепла 22. Система автономного електрозабезпечення містить систему перетворення постійного струму 23 можливістю подачі виробленої електричної енергії для інших споживачів 24. Генератор топкових газів 17 містить систему запірно-регулюючих вентилів 25 і 26, які забезпечують подачу потоку продуктів згоряння до АВХМ 15 і до інших споживачів 27.

АВХМ 15 містить генератор 28 з ВАР 29, бустер-компресор 30, конденсатор 3 повітряним охолодженням 31, дросельне пристрій рідкого аміаку 32, розсолу випарник 33, абсорбер 3 повітряним охолодженням 34, циркуляційний насос 35 міцного BAP (потік IVa), регенеративний теплообмінник 36 міцного і слабкого ВАР, повітряний охолоджувач потоку 37 слабкого BAP (потік IVб), дросельне пристрій слабкого ВАР 38.

Для відсікання потоку пара від бустеркомпресора 30 передбачені запірні вентилі 39 і 40.

Повітряне охолодження конденсатора 31, абсорбера 34 і охолоджувача 37 здійснюється вентиляторами, відповідно, 41, 42 і 43.

Робота системи охолодження молока на базі АВХМ здійснюється наступним чином.

Попередньо до початка охолодження молока проводять «зарядку» (охолодження) води в баціакумуляторі 5. Для цього використовують або систему радіаційного охолодження - панель 11 , або холодильну систему 14. Відповідно закривають вентилі 44 і 47 і відкривають вентилі 45 і 46, або навпаки.

При досягненні температури крижаної води до $1 \ldots 2{ }^{\circ} \mathrm{C}$ включають насос 9 і прокачують потоки Іа і Іб через охолоджуючу порожнину ємності 1, а потім заповнюють ємність 1 теплим молоком. За рахунок теплообміну молоко охолоджується до температури $4^{\circ} \mathrm{C}$ i охолоджений продукт за допомогою запірного клапана 3 зливають в ємність 4 для подальшого використання.

Далі цикл роботи системи охолодження повторюється.

Розглянемо деякі режими роботи установки для охолодження молока.

\section{"Нічний» режсим охолодження молока.}

Для охолодження розсолу використовується теплорассеівающіх панель 11, що забезпечує охо- лодження розсолу на $5 \ldots 10^{\circ} \mathrm{C}$ нижче атмосферного повітря. Такий режим охолодження може бути ефективно використаний в зимовий час і перехідні періоди року (весна-осінь) без холодильної системи. Розсіл за допомогою насоса 10 прокачується по теплообміннику 8 при відкритих вентилях 46 i 45 і закритих вентилях 44 i 47. За рахунок радіаційного охолодження пластини 11 проводиться охолодження розсолу в каналах 12 .

У «нічному» режимі використовується як природний холод атмосфери Землі, так і радіаційне випромінювання в космічний простір, а електрична енергія використовується тільки для роботи циркуляційного насоса 10.

\section{"Денний» режим охолодження молока.}

Вікорістовується холодильна система 14 при відкритих вентилях 44 и 47 и закритого акціонерного вентилях 46 и 45. Розсіл насосом 10 прокачується через випарник 33 АВХМ 15.

У «денному» режімі охолодження можна віділіті два режими роботи холодильної системи 14.

Упершому випадку вікорістовується только поновлюване джерело теплової енергії - сонячне теплове випромінювання.

Оптимальні співвідношення ціни и якості мають сонячні колектори 16 з водою в якості теплоносія. Характерна їх особлівість - робочий рівень температур не вищє $100^{\circ} \mathrm{C}$.

При відсутності потреби в штучному холоді тепловий потік від сонячних колекторів может буті переключено на других спожівачів теплової енергії 22 при відкрітому вентилі 20 и закритих вентилях 19 и 21.

Робочий рівень температур в генераторі традіційніх АВХМ становить $120 \ldots 140{ }^{\circ} \mathrm{C}$, що перевіщує температурний потенціал теплоносія-води в сонячном колекторі 16. У зв'язку з цим використовується схема АВХМ 3 підтіскаючим бустеркомпресором 30 перед конденсатором 31 [22]. У схемі АВХМ 15 існує можлівість відсікання бустер-компресора 30 від парового потоку запорним вентилем 39 при зміні температурних параметрів подачі теплового навантаження в генератор 28.

Робота ABXM 15 з сонячним колектором 16 здійснюється наступним чином.

При подачі гарячої води від сонячних колекторів в генератор 28 здійснюється кипіння міцного BAР з виходом легкокіплячого компонента - аміаку. При подачі пара аміаку на бустер-компресор 30 вентиль 39 відкритий, а вентиль 40 - закритий.

Пар аміаку стискається бустер-компресором 30 и подається в конденсатор 31, де зріджується 3 відведенням теплоти пароутворення в навколишнє середовище. Відведення тепла фазового переходу 3 конденсатора 31 здійснюється за помощью повітряного вентилятора 41. 
Зрідженій аміак 3 конденсатора 31 через дросельний пристрій 32 надходить у випарник 33 , де його тиск знижується. Відбувається нізькотемпературне кипіння рідкого аміаку з відведенням тепла від циркулюючого потоку розсолу. Утворений в випарнику 33 пар надходить в абсорбер 34, куди, в свою чергу, підходить слабкий ВАР 3 генератоpa 28.

До надходження в абсорбер 34 слабкий ВАР охолоджується в регенеративному противоточному теплообмінніку розчінів 36 і охолоджувачі 37 и в результате становится ненасиченім по аміаку. У абсорбере 34 при контакті слабкого ВАР з парою аміаку відбувається процес абсорбції. В результате слабкий ВАР насичується и становится «міцним» (насиченим по аміаку). У процесі абсорбції віділяється тепло, яке відводіться вентилятором 42 в навколишнє середовище. Міцний ВАР $з$ абсорбера насосом 35 через регенеративні теплообмінник 36 подається назад в генератор 28 и цикл далі повторюється.

Робота бустер-компресора 30 и насоса 35 здійснюється за рахунок роботи сонячної батареї 18 і системи перетворювання и акумулювання електричної енергії 23. Система 23 так само дозволяє перерозподіляті, при необхідності, електричну енергію для других спожівачів 24 .

При іншому режімі роботи холодильної системи 14 подача теплової навантаження в генератор 28 АВХМ 15 здійснюється відходними продуктами згоряння з температурою $350 \ldots 450{ }^{\circ} \mathrm{C}$ від генератора газів 17.

У цьому випадку можемо використовувати широкий асортимент органічніх палів: природний газ, пропан-бутан, бензин, гас, вугілля, дрова, торф та ін.

Температурного потенціалу потоку продуктів згоряння досить, щоб АВХМ 15 працювала без участі підтіскаючого бустер-компресора 30 . У цьом випадка вентиль 39 закритий, а вентиль 40 відкритий.

Робота АВХМ 15 далі здійснюється наведеним вищє способом.

Таким чином, розроблені схеми систем охолодження дозволяють 3 мінімальнімі витратами мережевий електричної енергії и води здійснювати первинне охолодження молока. Найбільш перспективною сферою застосування таких систем станут селянські и фермерські господарства.

\section{7. Аналіз результатів розробки автономних систем охолодження на базі поновлюва- них і непридатних джерелах теплової енер- riï}

Отримані результати в частині застосування альтернативних поновлюваних джерел енергії дозволили запропонувати нові технічні схеми систем охолодження, що характеризуються мінімальним споживанням електричної енергії.

По-перше, це технологія НРО. Вона дозволяє використовувати в системах охолодження не тільки природний низькотемпературний потенціал атмосферного повітря, але і радіаційне випромінювання в космічний простір. У холодну пору року ця технологія дозволяє вирішувати завдання охолодження без участі холодильних машин. У перехідні і теплий період року до технології НРО необхідно підключати системи штучного охолодження. У світлий час доби - це сонячні колектори i сонячні батареї. Вони дозволяють здійснювати роботу АВХМ 3 бустер-компресором перед конденсатором на температурному рівні від 50 до 90 ${ }^{\circ} \mathrm{C}$.

Цілодобову роботу АВХМ можна забезпечити за рахунок роботи горелочного пристрою практично будь-якого типу з використанням, в тому числі, відходів сільськогосподарського виробництва.

Слід зазначити і можливість АВХМ забезпечити широкий діапазон температур охолодження (мінус $30 \ldots 15{ }^{\circ} \mathrm{C}$ ), особливо при роботі горелочного пристрою.

Технологія НРО, особливо в холодну пору року, дозволяє ефективно відводити тепло від конденсатора і використовувати ПКХМ з мінімальною потужністю компресора. Так, при температурі конденсатора $10^{\circ} \mathrm{C}$ має місце зростання коефіцієнта перетворення ПКХМ в 4-6 разів, а для аміаку - в 17,3 рази.

На відміну від аналогів малопотужна ПКХМ може працювати від сонячних батарей в світлий час доби і забезпечувати запас штучного холоду в спеціальному холодоаккумуляторі.

До проблемних технічних моментів запропонованих схемних рішень можна віднести наступне.

По-перше, під час пуску навіть малопотужної ПКХМ треба вирішувати проблему пускових струмів. Сучасні електричні акумулятори не дозволяють забезпечити запуск з струмами, що перевищують в 4-6 разів номінальні значення. Рішенням проблеми може бути запуск від стаціонарної електромережі з переходом на сонячні батареї. Через незначною потужності бустер-компресора (до $100 \mathrm{BT}$ ) в схемі запропонованої АВХМ може бути використана конструкція 3 постійним струмом, яка не має проблем з запуском.

При подальшому вдосконаленні автономних систем охолодження слід звернути увагу на технологію акумулювання природного і штучного холоду.

Необхідно підібрати відповідний матеріал і розрахувати, як габарити холодоаккумулюючої ємності, так систему теплообмінників. 
3 урахуванням особливостей розсіювання тепла в різних атмосферних середовищах $[8,18]$ найбільший ефект від технології НРО в системах холодильної техніки може бути досягнутий в високогірних районах планети 3 мінімальною вологістю атмосферного повітря, наприклад, в Казахстані та інших країнах Середньої Азії. Застосування HРO в інших регіонах планети вимагає, в першу чергу, експериментальної перевірки та оцінки економічної доцільності.

При добовій циклічності процесу відведення тепла холодильного циклу в режимі НРО ключовим моментом в схемах систем охолодження молока $є$ наявність бака-акумулятора холоду. Акумуляція холоду дозволить вирішувати завдання організації завдань охолодження молока в оптимальному режимі господарювання.

\section{Висновки}

1. Проведено аналіз циклів АВХМ в широкому діапазоні робочих термодинамічних параметрів (температури гріючого середовища: від 47 до 140 ${ }^{\circ} \mathrm{C}$, температура навколишнього середовища: $17 . .47{ }^{\circ} \mathrm{C}$, температура об'єкта охолодження: мінус $\left.30 \ldots 5^{\circ} \mathrm{C}\right)$. Виконано пошук мінімально необхідної температури гріючого середовища, яка забезпечує максимально можливу енергетичну ефективність циклу реальної АВХМ (з урахуванням недорекуперціi в теплообмінниках) в залежності від температур об'єкта охолодження і охолоджуючої середовища. Показано, що при реалізації таких циклів АВХМ є режими 3 максимальною енергетичною ефективністю в практичних діапазонах температур охолоджуючої середовища (від 10 до $32{ }^{\circ} \mathrm{C}$ ) і об'єктів охолодження (від мінус 25 до мінус $5{ }^{\circ} \mathrm{C}$ ). Для досягнення таких оптимальних режимів необхідно відповідна комбінація складу міцного ВАР і температури що гріє джерела.

2 Проведено аналіз особливостей роботи ПКХМ в широкому діапазоні температур навколишнього середовища, в тому числі і в умовах низьких температур атмосферного повітря (до 10 $\left.{ }^{\circ} \mathrm{C}\right)$. Показані значні енергетичні переваги при роботі конденсатора ПКХМ в умовах низьких температурах атмосферного повітря. Як робоче тіло ПКХМ рекомендований аміак (R717), що забезпечує максимальну енергетичну ефективність серед розглянутих аналогів: R134a, R22, R600 (ізобутан), $\mathrm{R} 744\left(\mathrm{CO}_{2}\right)$.

3. Розроблено перспективні схеми автономних систем охолодження на базі ПКХМ і АВХМ 3 використанням альтернативних поновлюваних джерел енергії, в тому числі і з використанням технології НРО. При роботі в системах охолодження АВХМ з сонячними колекторами з водою, в якості теплоносія, запропонована схема з бустеркомпресором перед конденсатором.

\section{Література}

1. Босин И.Н. Охлаждение молока на комплексах и фермах. М.: Колос, 1993. 46 с.

2. Перельштейн Б.X. Новые энергетические системы. Казань: Изд-во Казан. гос. техн. ун-та, 2008. $244 \mathrm{c}$.

3. Морозюк Л.И. Теплоиспользующие холодильные машины - пути развития и совершенствования//Холодильна техніка та технологія. 2014. № 5(151). C.23-29. DOI: http://dx.doi.org/ 10.15673/0453-8307.5/2014.28695.

4. Титлов А. С., Сагала, Т. А., Артюх, В. Н., Дьяченко, Т. В. Анализ перспектив использования пароэжекторной и абсорбционной холодильных установок для охлаждения технологического газа и получения жидкого углеводородного топлива//Холодильная техника и технология. 2017. № 53(6). C.11-18. https://doi.org/10.15673/ret. v53i6.920.

5. Морозюк Л.И. Развитие теории и методов исследования процессов преобразования и получения тепла и холода в установках с многокомпонентными и многофазными рабочими веществами: дис. док. тех. наук: 05.14.06 / Л. И. Морозюк. - ОНПУ, Одесса, 2013. - 352 с.

6. Титлов А.С. Сравнение характеристик абсорбционной и компрессионной бытовой холодильной техники//Холодильная техника и технология. 1997. № 57. C. 39-41.

7. Kimball B.A. Cooling performance and efficiency of night sky radiators. Solar Energy Vol. 34, No. 1, Elsevier Science Ltd. Printed in the U.S.A. 1985. P. 19-33.

8. Цой А.П., Грановский А.С., Цой Д.А., Бараненко А.В. Влияние климата на работу холодильной системы, использующей эффективное излучение в космическое пространство // Холодильная техника. 2015. №1. С. 43-47.

9. Yong C. et al., Performance analysis on a building-integrated solar heating and cooling panel//Renewable Energy. 2015. № 74. P. 627-632.

10. Zhiguang Zhou, Xingshu Sun, Peter Bermel, Radiative cooling for thermophotovoltaic systems. Infrared Remote Sensing and Instrumentation XXIV, San Diego, California, August 28, 2016.

11.Prommajak T., Phonruksa J., Pramuang S. Passive cooling of air at night by the nocturnal radiation in Loei, Thailand / T. Prommajak, //Int. J. Renew. Energy. 2008. V. 3. № 1. P. 33-40.

12.Eleftherios Bourdakis, Ongun B. Kazanci, Bjarne W. Olesen, F. Grossule, Simulation Study of Discharging PCM Ceiling Panels through Night - time Radiative Cooling. ASHRAE Annual Conference, St. 
Louis, 2016.

13.Imroz Sohel M., Zhenjun Ma, Paul Cooper, Jamie Adams, Lloyd Niccol and Stefan Gschwander, A Feasibility Study of Night Radiative Cooling of BIPVT in Climatic Conditions of Major Australian Cities. Asia - Pacific solar research conference, November 2014.

14.Цой А. П., Бараненко А.В., Эглит А.Я. Использование эффективного излучения в холодильной системе открытого катка//Вестник Международной Академии Холода. - 2012. № 4. C. 8-11.

15. Bosholm F., López-Navarro, Gamarra A.M. , Corberán J.M., Payá J. Reproducibility of solidification and meltingprocesses in a latent heat thermal storage tank//International journal of refrigeration. 2016. № 62 . P. 85-96.

16.Sutyaginsky M.A., Maksimenko V.A., Potapov Ya.A., Suvorov A.P., Dubok V.N. The use of lowtemperature potential of the environment in energyefficient refrigeration supply technologies of the enterprises of $\mathrm{GC}$ «Titan»//Elsevier. International Conference on Oil and Gas Engineering, OGE-2016. Procedia Engineering. 2016. № 152. P. 361-365.

17.Berdahl P., Matin M. and Sakkal F. The Thermal Performance of Radiative Cooling Panels//Int. J. Heat Mass Transfer. 1983. № 26. P. 871-880.

18. Цой А.П., Грановский А.С., Цой Д.А., Бараненко А.В. Влияние климата на работу холодильной системы, использующей эффективное излучение в космическое пространство // Холодильная техника. 2014. № 12. С. 36-41.

19.Ищенко И.Н. Перспективы применения абсорбционных водоаммиачных холодильных машин в системах получения воды из атмосферного воздуха / И.Н. Ищенко, А.С. Титлов, А.Н. Краснопольский // Збірник наукових праць Вінницького національного аграрного університету. Серія: Технічні науки. - Вип. 7. 2011. - C.92-97.

20.Doroshenko A. Comparative field experimental investigations of different flat plate solar collectors//Solar Energy. 2016. 115. P. 577-588.

21. Осадчук Е.А., Титлов А.С., С.Ю. Мазуренко С.Ю. Определение энергетически эффективных режимов работы абсорбционной водоаммиачной холодильной машины в системах получения воды из атмосферного воздуха//Холодильна техніка та технологія. 2014. № 4. С. 54-57.

22.Спосіб одержання води 3 атмосферного повітря: пат. 104854 Україна. № u 2015 07386; заявл. 23.07.2015; опубл. 25.02.2016, Бюл. № 4.

23.Спосіб одержання води 3 атмосферного повітря: патент 100195 Україна. № u201501512; заявл. 20.02.2015; опубл. 10.07.2015, Бюл. № 9.

24.Титлов А.С. Научно-технические основы энергосбережения при проектировании холодильных аппаратов с абсорбционно-диффузионными холодильными машинами//Наукові праці Одеської національної академії харчових технологій. 2006. № 29. T. 1. C. 194-200.

25. Осадчук Е.А., Титлов А.С. Аналитические зависимости для расчета термодинамических параметров и теплофизических свойств водоаммиачного раствора. Наукові праці ОНАХТ. 2011. № 39. T.1. C.178-182.

26.Осадчук Е.А. Титлов А.С., Кузаконь В.М., Шлапак Г.В. Разработка схем насосных и безнасосных абсорбционных водоаммиачных холодильных машин для работы в системах получения воды из атмосферного воздуха//Технологический аудит и резервы производства. 2015. № 3/3(23). C. 30-37. DOI: 10.15587/2312-8372.2015.44139.

27. Ищенко И. Н. Моделирование циклов насосных и безнасосных абсорбционных холодильных агрегатов//Наукові праці ОНАХТ. 2010. № 38. T.2. C. 393-405.

28.Цой А.П., Грановский А.С., Мачуев Ю.И., Филатов А.С. Обзор проведенных экспериментальных исследований эффективного излучения холодильной системы в космическое пространство // Вестник МАХ. 2015. № 3. С 28-33.

29.Мартыновский В.С., Мельцер Л.3., Минкус Б.А. Холодильные машины: справочник. М.: Легкая и пищевая пром-ть. 1982. - 223 с.

30.Pega Hrnjak. Efficient very low charged ammonia systems. 7th IIR Conference: Ammonia and $\mathrm{CO} 2$ Refrigeration Technologies, Ohrid, 2017. doi: 10.18462/iir.nh3-co2.2017.000

Отримана в редакції 12.02.2019, прийнята до друку 02.04.2019

\title{
Development of autonomous cooling systems on the basis of renewable and cable sources of heat energy
}

\author{
O. S. Titlov ${ }^{1}$, E.O. Osadchuk ${ }^{1}$, O. P. Tsoy ${ }^{2}$, A. Kh. Alimkeshova ${ }^{2}$, R. A.Dzhamasheva ${ }^{2}$ \\ ${ }^{1}$ Odessa National Academy of Food Technologies, 112 Kanatna str, Odesa, 65039, Ukraine \\ ${ }^{2}$ Almaty Technological University, 100 Tole bi str., Almaty, 050012, Republic of Kazakhstan
}

The analysis of the possibilities of using night radiation cooling (NRC) for additional heat removal from the elements of the liquid cooling system was performed. The energy prospects of using NRC technology for 
autonomous primary cooling systems mainly in rural and peasant farms located in remote areas from sources of electrical energy are shown. To improve the energy efficiency of autonomous cooling systems, it was proposed to use absorption water-ammonia refrigerator (AWAR) and compression refrigerator (CR), which will allow to create cold reserves in the cold-accumulation system during daylight hours. To work AWAR proposed to use thermal energy of solar radiation. A methodology for modeling the AWAR modes has been developed and an analysis of the results obtained in a wide range of operating thermodynamic parameters (ambient temperature - $17 \ldots 47{ }^{\circ} \mathrm{C}$, temperature of the cooling object - minus $30 \ldots 15{ }^{\circ} \mathrm{C}$ ). The methodology is based on the original algorithm for finding the minimum required temperature of the heating medium, depending on the temperature of the cooling object and the cooling medium of the real AWAR. It is shown that when implementing traditional AWAR cycles, there are regimes with maximum energy efficiency, and to achieve them, an appropriate combination of working fluid composition (water-ammonia solution) and temperature of the heating source is required. It is also shown that when working from solar collectors with water as a coolant, it is necessary to include a booster-compressor in front of the ammonia condenser in the AWAR circuit. A thermodynamic analysis of CR cycles operating on currently approved working bodies was performed. High energy characteristics of $C R$ are noted when operating at low ambient temperatures. Thus, with a decrease in the temperature of atmospheric air from $40^{\circ} \mathrm{C}$ to $10{ }^{\circ} \mathrm{C}$, on average, there is an increase in the refrigeration coefficient of cycles of CR by 4-6 times, and for ammonia - by 17.3 times. Original schemes of primary milk cooling systems based on CR and AWAR using NRC technology have been developed, which allow working in autonomous mode using the minimum amount of electrical energy.

Key words: night radiation cooling, solar absorption water-ammonia refrigerator, milk cooling

\section{References}

1. Bosini I.N. (1993). Okhlazhdeniye moloka na kompleksakh i fermakh. $M$.: Kolos. 46 p.

2. Perel'shteyn B.Kh. (2008) Novyye energeticheskiye sistemy. Kazan': Izd-vo Kazan. gos. tekhn. un-ta. $244 \mathrm{p}$.

3. Morozyuk L.I. (2014) Teploispol'zuyushchiye kholodil'nyye mashiny - puti razvitiya i sovershenstvovaniya. Kholodil'naya tekhnika $i$ tekhnologiya, 5 (151), 23-29. DOI: http://dx.doi.org/10.15673/0453-8307.5/2014.28695.

4. Titlov A. S., Sagal, T. A., Artyukh, V. N., D'yachenko, T. V. (2017) Analiz perspektiv ispol'zovaniya paroezhektornoy i absorbtsionnoy kholodil'nykh ustanovok dlya okhlazhdeniya tekhnologicheskogo gaza i polucheniya zhidkogo uglevodorodnogo topliva. Kholodil'naya tekhnika $i$ tekhnologiya, $\quad 53 \quad$ (6), 11-18. https://doi.org/10.15673/ret.v53i6.920.

5. Morozyuk L.I. (2013) Razvitiye teorii i metodov issledovaniya protsessov preobrazovaniya $\mathrm{i}$ polucheniya tepla $\mathrm{i}$ kholoda $\mathrm{v}$ ustanovkakh $\mathrm{s}$ mnogokomponentnymi i mnogofaznymi rabochimi veshchestvami: dic. dok. tekh. nauk: 05.14.06 / L. I. Morozyuk. - ONPU, Odessa. 352 p.

6. Titlov A.S. (1997) Sravneniye kharakteristik absorbtsionnoy i kompressionnoye bytovoy kholodil'noy tekhniki. Kholodil'naya tekhnika $i$ tekhnologiya, 57, 39-41.

7. Kimball B.A. (1985) Cooling performance and efficiency of night sky radiators. Solar Energy, V.34, 1, Elsevier Science Ltd. Printed in the U.S.A, 19-33.
8. Tsoy A.P., Granovskiy A.S., Tsoy D.A., Baranenko A.V. (2015) Vliyaniye klimata na rabotu kholodil'noy sistemy, ispol'zuyushchey effektivnoye izlucheniye v kosmicheskoye prostranstvo. Kholodil'naya tekhnika, 1, 43-47.

9. Yong C. et al. (2015) Performance analysis on a building-integrated solar heating and cooling panel. Renewable Energy, 74, 627-632.

10. Zhiguang Zhou, Xingshu Sun, Peter Bermel. (2016) Radiative cooling for thermophotovoltaic systems. Infrared Remote Sensing and Instrumentation XXIV, San Diego, California, August 28.

11. Prommajak T., Phonruksa J., Pramuang S. (2008) Passive cooling of air at night by the nocturnal radiation in Loei, Thailand. Int. J. Renew. Energy. V. $3,1,33-40$.

12. Eleftherios Bourdakis, Ongun B. Kazanci, Bjarne W. Olesen, Grossule F. (2016). Simulation Study of Discharging PCM Ceiling Panels through Night- time Radiative Cooling. ASHRAE Annual Conference, St. Louis.

13. Imroz Sohel M., Zhenjun Ma, Paul Cooper, Jamie Adams, Lloyd Niccol and Stefan Gschwander (2014) A Feasibility Study of Night Radiative Cooling of BIPVT in Climatic Conditions of Major Australian Cities. Asia - Pacific solar research conference, November.

14. Tsoy A. P., Baranenko A.V., Eglit A.Ya. (2012) Ispol'zovaniye effektivnogo izlucheniya $\mathrm{v}$ kholodil'noy sisteme otkrytogo katka. Vestnik Mezhdunarodnoy Akademii Kholoda, 4, 8-11.

15. Bosholm F., López-Navarro, Gamarra A.M., 
Corberán J.M., Payá J. (2016) Reproducibility of solidification and meltingprocesses in a latent heat thermal storage tank. International journal of refrigeration, 62, 85-96.

16. Sutyaginsky M.A., Maksimenko V.A., Potapov Ya.A., Suvorov A.P., Dubok V.N. (2016) The use of low-temperature potential of the environment in energy-efficient refrigeration supply technologies of the enterprises of GC «Titan». Elsevier. International Conference on Oil and Gas Engineering, OGE-2016. Procedia Engineering, 152, 361-365.

17. Berdahl P., Matin M. and Sakkal F. (1983) The Thermal Performance of Radiative Cooling Panels. Int. J. Heat Mass Transfer, 26, 871-880.

18. Tsoy A.P., Granovskiy A.S., Tsoy D.A., Baranenko A.V. (2014) Vliyaniye klimata na rabotu kholodil'noy sistemy, ispol'zuyushchey effektivnoye izlucheniye v kosmicheskoye prostranstvo. Kholodil'naya tekhnika, 12, 36-41.

19. Yshchenko Y.N., Titlov A.S., Krasnopolsky A.N. (2011). Perspektyvy prymenenyya absorbtsyonnykh vodoammyachnykh kholodyl'nykh mashyn $\mathrm{v}$ systemakh poluchenyya vody yz atmosfernoho vozdukha. Zbirnyk naukovykh prats' Vinnyts'koho natsional'noho ahrarnoho universytetu. Seriya: Tekhnichni nauky, 7, 92-97.

20. Doroshenko A. (2016) Comparative field experimental investigations of different flat plate solar collectors. Solar Energy, 115, 577-588.

21. Osadchuk Y.A., Titlov A.S., Mazurenko S.Y. (2014) Opredeleniye energeticheski effektivnykh rezhimov raboty absorbtsionnoy vodoammiachnoy kholodil'noy mashiny v sistemakh polucheniya vody iz atmosfernogo vozdukha. Kholodil'na tekhníka ta tekhnologíya, 4, 54-57.

22. Sposíb oderzhannya vodi $\mathrm{z}$ atmosfernogo povítrya: pat. 104854 Ukraïna. № u 2015 07386; zayavl. 23.07.2015; opubl. 25.02.2016, Byul. № 4 .
23. Sposíb oderzhannya vodi z atmosfernogo povítrya: patent 100195 Ukraïna. № u201501512; zayavl. 20.02.2015; opubl. 10.07.2015, Byul. № 9 .

24.Titlov A.S. (2006) Nauchno-tekhnicheskiye osnovy energosberezheniya pri proyektirovanii kholodil'nykh apparatov s absorbtsionnodiffuzionnymi kholodil'nymi mashinami. Naukoví pratsi Odes'koï natsional'noï akademiï kharchovikh tekhnologíy, 29, T. 1, 94-200.

25. Osadchuk Y.A., Titlov A.S. (2011) Analiticheskiye zavisimosti dlya rascheta termodinamicheskikh parametrov i teplofizicheskikh svoystv vodoammiachnogo rastvora. Naukoví pratsi ONAKHT, 39, T.1, 178182.

26.Osadchuk Y.A. Titlov A.S., Kuzakon' V.M., Shlapak G.V. (2015) Razrabotka skhem nasosnykh i beznasosnykh absorbtsionnykh vodoammiachnykh kholodil'nykh mashin dlya raboty $\mathrm{v}$ sistemakh polucheniya vody iz atmosfernogo vozdukha. Tekhnologicheskiy audit $i$ rezervy proizvodstva, 3/3(23), $\quad 30-37 . \quad$ DOI: $\quad 10.15587 / 2312-$ 8372.2015.44139.

27. Ishchenko I. N. (2010) Modelirovaniye tsiklov nasosnykh i beznasosnykh absorbtsionnykh kholodil'nykh agregatov.Naukovi pratsi ONAKHT, 38, T.2, 393-405.

28.Tsoy A.P., Granovskiy A.S., Machuyev YU.I., Filatov A.S. (2015) Obzor provedennykh eksperimental'nykh issledovaniy effektivnogo izlucheniya kholodil'noy sistemy v kosmicheskoye prostranstvo. Vestnik MAKH, 3, 28-33.

29. Martynovskiy V.S., Mel'tser L.Z., Minkus B.A. (1982) Kholodil'nyye mashiny: spravochnik. M.: Legkaya i pishchevaya prom-t'. 223 p.

30.Pega Hrnjak. Efficient very low charged ammonia systems (2017). 7th IIR Conference: Ammonia and $\mathrm{CO} 2$ Refrigeration Technologies. doi: 10.18462/iir.nh3-co2.2017.000 